\title{
Isolation and Molecular Identification of Duck Hepatitis A Virus in Sharkia Governorate
}

\author{
Mohamed N. Hassaan ${ }^{1 *}$, Abeer M. Shahin ${ }^{2}$ and Amal A.M. Eid ${ }^{2}$ \\ ${ }^{1}$ Veterinary Hospital, Faculty of Veterinary Medicine, Zagazig University, 44511, Egypt \\ ${ }^{2}$ Avian and Rabbit Medicine Department, Faculty of Veterinary Medicine, Zagazig University, \\ 44511, Egypt \\ Article History: Received: 8/2/2018 Received in revised form: 23/2/2018 Accepted: 28/2/2018
}

\begin{abstract}
Thirty two flocks were examined to investigate the incrimination of DHAV in the nervous signs and massive mortalities recorded among ducklings during 2014-2016 in Sharkia Governorate. The examined birds aged (2-11 days) were suffering from nervous signs; ataxia followed by opisthotonos, kicking spasmodically then rapid death. Enlarged liver with marked petechial haemorrhages, enlarged spleen, nephritis and swelling of the kidneys were seen. Viral isolation in ECE revealed stunting, subcutaneous hemorrhages covering the body, necrotic areas and greenish discoloration of embryonic liver in 22 samples $(68.75 \%)$. DHAV identification was succeeded by RT-PCR using RNA extracted from the livers of collected samples and specific primers based on 3D gene in all above positive samples. It could be concluded that RT-PCR could be carried out on hepatic tissues for rapid diagnosis of common DHAV. The subtyping of DHAV is useful for accurate diagnosis to avoid vaccination failure.
\end{abstract}

Keywords: DHAV, Molecular identification.

\section{Introduction}

An acute contagious, rapidly spreading and highly lethal viral infection of young ducklings was recorded by Woolcock [1]. The disease causes highly economic losses in ducklings due to high mortalities. There are three heterologus duck hepatitis virus (DHV) types; I, II and III [1]. The DHV type I has spread worldwide with mortalities more than $80 \%$ in ducklings less than 3 weeks of age [2]. Currently, DHV type I is renamed duck hepatitis A virus (DHAV) and subdivided into three genotypes DHAV-1, DHAV-2 and DHAV-3 [3]. There is a limited crossneutralization between DHAV-1 and DHAV-3 [4]. However, no cross-neutralization was found between DHAV-1 and DHAV-2 [5]. On the other hand, the DHV type II and DHV type III are members of the astroviridae and renamed as duck astrovirus type I (DAstV-I) and duck astrovirus type II (DAstV-II) respectively [6]. The DHAV was firstly isolated in white pekin ducklings on Long Island on New York during the spring of 1949 [7]. In Egypt, Refaie [8] identified DHAV from Pekin, Balady and Rowan sick ducklings for the first time. Recently, Sultan and Talaat [9]; Erfan et al., [10]; Bayoumie and Abd ELSamie, [11] and EL-Samadony et al., [12] studied molecular characterization and epidemiology of DHAV from different duck breeds in Egypt. The DHAV is a nonenveloped single stranded RNA genome of approximately $7.8 \mathrm{~kb}$ [13]. It is icosahedral particle, resistant to ether and chloroform and capable of survival for long periods under natural environmental circumstances [1].

Transmission of duck virus hepatitis (DVH) infection can arise from aerosols or oral route [14]. Recovered ducks may excrete virus in dropping up to 8 weeks PI [15]. Wild birds were incriminated as mechanical carrier of virus over short distances and healthy carriers were responsible for new outbreaks at great distances [16].

Morbidity can reach $100 \%$, with $95 \%$ mortality in ducklings less than one week and may reach $50 \%$ or less in ducklings between 13 weeks of age [17].

The disease is characterized by imbalance, lethargy and ataxia in ducklings which are falling on their sides and kicking spasmodically followed by opisthotonos within 1-2 hours prior to death. Marked petechial and or ecchymotic haemorrhages are the mostly seen lesions in enlarged liver of affected ducklings. Enlarged spleen and kidneys with some congestion of renal blood vessels may also occur in DHAV infection [6].

*Corresponding author email: (mohammednazeh30@gmail.com), Veterinary Hospital, Faculty of 
Histopathologically, hepatocytic necrosis and bile duct hyperplasia with haemorrhage and inflammatory cells aggregations are seen in livers [6]. Virus isolation in embryonated chicken egg (ECE) is commonly used through inoculation of the liver homogenate into the allantoic sac of ECE (8-10 days) [17]. Pathological lesions in the embryos include stunting and edema of the abdominal and hind limbs, with subcutaneous haemorrhages over the whole body. Livers may be red and yellowish, swollen and may have some necrotic foci. Greenish allantois is more obvious in survived embryos [6].

Up to 2005, DHAV was detected only associated with causing disease in Mallard and Pekin ducklings but in the last decade, it is reported to cause pancreatitis and encephalitis in Muscovy ducks [18]. The diagnosis of DHAV is usually based on epidemiological information, clinical signs, pathological changes and viral isolation $[19,20]$ and the methods for detection of antibody against DHAV in duck sera include neutralization tests [21, 22] indirect hemagglutination tests [23] gel diffusion assays [24] and ELISA [25]. These assays are time-consuming and don't provide the needed sensitivity to detect lowlevel of virus [26]

Reverse transcriptase polymerase chain reactions (RT-PCR) have been established and are beneficial for identifying DHAV infection [27] beside sequencing of VP1 genes to detect mutations [28].

The current work aimed to confirm DHAV responsibility on losses of ducklings at Sharkia Governorate. This goal was investigated via virus isolation in ECE and detection by RTPCR.

\section{Material and Methods}

\section{Sampling}

Liver and spleen tissue pools (3/each) were collected from 32 duckling flocks from different localities at Sharkia Governorate. The examined birds aged (2-11 days) from February 2014 to April 2015. These flocks are progeny of vaccinated duck breeders against DHAV and had a history of high mortality rate and nervous signs.

\section{Sample preparation and virus isolation}

Tissue suspension of collected samples was prepared [4]. An inoculum of $0.2 \mathrm{ml}$ prepared with $10 \% \quad(w / v)$ PBS with antibiotics (penicillin $10000 \mathrm{IU} / \mathrm{ml}$ and streptomycin 10 $\mathrm{mg} / \mathrm{ml}$ ) was used for virus isolation in ECE. The embryos were examined for any pathological lesions [6].

\section{Histopathological Examination}

Liver speciments of affected ducklings were fixed in $10 \%$ buffered neutral formalin solution, processed in paraffin sections (5 microns thickness) and stained with haematoxylin and eosin (H\&E) , then examined microscopically [29].

\section{RNA Extraction}

Viral RNA was extracted from $50 \mu \mathrm{l}$ of supernatant of affected liver and spleen tissue pools by Gene JET RNA Purification Kit according to the manufacturer's instruction (ferments\#K0731). The cDNA used immediately for PCR or stored at $-20^{\circ} \mathrm{C}$.

\section{PCR reaction}

The PCR was performed in a total of $25 \mu 1$ in a sterile $0.2 \mathrm{ml}$ RNase free PCR tubes. For one reaction, the assay was optimized to 12.5 $\mu$ l of DreamTaq Green PCR master mix $(2 \mathrm{X}), \quad 0.25 \mu \mathrm{l}$ of appropriate forward and reverse primers (100 pmole/ $\mu \mathrm{l}), 2 \mu \mathrm{l}$ of cDNA and 10ul of RNase-free water.

A specific pair of primers were used the forward ComF (5'-AAG AAG-GAG-AAAATY-[C or T]-AAG-GAA-GG-3') and the reverse one ComR(5'-TTG-ATG-TCA-TAGCCC-AAS-[C or G]-ACA-GC-3') based on 3D gene.

The optimized PCR cyclic reaction conditions were performed in MWG-Biotech Thermal cycler and described as following, initial denaturation at $95^{\circ} \mathrm{C}$ for $3 \mathrm{~min}$, followed by 37 cycles of denaturation at $95^{\circ} \mathrm{C}$ for $30 \mathrm{sec}$, annealing at $50^{\circ} \mathrm{C}$ for $30 \mathrm{sec}$ and extension at $72^{\circ} \mathrm{C}$ for $60 \mathrm{sec}$. A final extension step at $72^{\circ} \mathrm{C}$ for 10 minutes was also performed [4]. 


\section{Agarose gel electrophoresis of RT-PCR product}

The $1.5 \%$ agarose gel was prepared in $1 \mathrm{X}$ TAE buffer and $50 \mu \mathrm{l}$ of ethidium bromide was added to melted agarose to give total concentration of $0.5 \mu \mathrm{g} / \mathrm{ml}$. Electrophoresis was done at 100 volts for $40 \mathrm{~min}$, then the bands were viewed by UV trans-illuminator [4].

\section{Results}
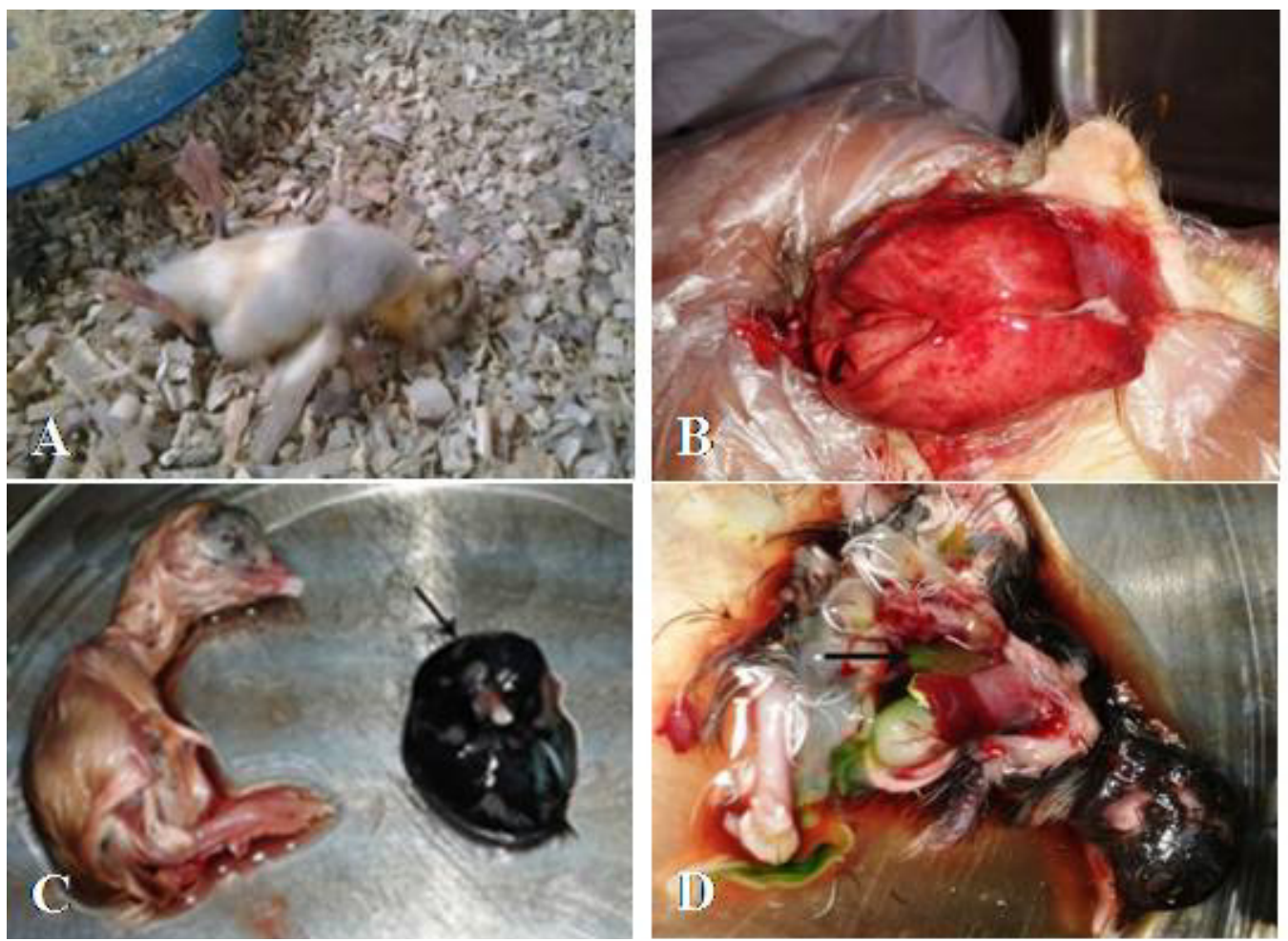

Figure 1: (1 A-D): A: Pekin ducklings, 6 days-old, flock number 9 showing opisthtonous. B: Liver of pekin ducklings, 11 days-old, flock number 8, showing petecheal haemorrage. C: Dead embryo of flock number 12 showing stunting 7 days PI compared with the control (arrow head). D: Liver of dead embryo showing greenish discoloration (arrow) in flock number 12

\section{Virus isolation}

The inoculated ECE showed pathological changes as stunting embryos with subcutaneous hemorrhages covering the body and edema in the hind limbs and abdominal region in 22 out of 32 examined samples (Figure $1 \mathrm{C}$ ). The embryonic liver was enlarged, greenish in color, also showed some necrotic foci (Figure 1 D). The allantoic fluid

\section{Clinical findings}

The examined ducklings under current study were suffering from nervous signs including ataxia followed by opisthotonos (loss of balance falling on their sides and kick spasmodically) then death (Figure $1 \mathrm{~A}$ ). The postmortem findings appeared mainly in the liver, which was enlarged and displayed distinct petechial and/or ecchymotic hemorrhages (Figure $1 \mathrm{~B}$ ). 
with aggregation of inflammatory cells and mild fatty changes of hepatocytes (Figure 2C).
Portal area showed congested blood vessels and lymphatic infiltration (Figure 2D).
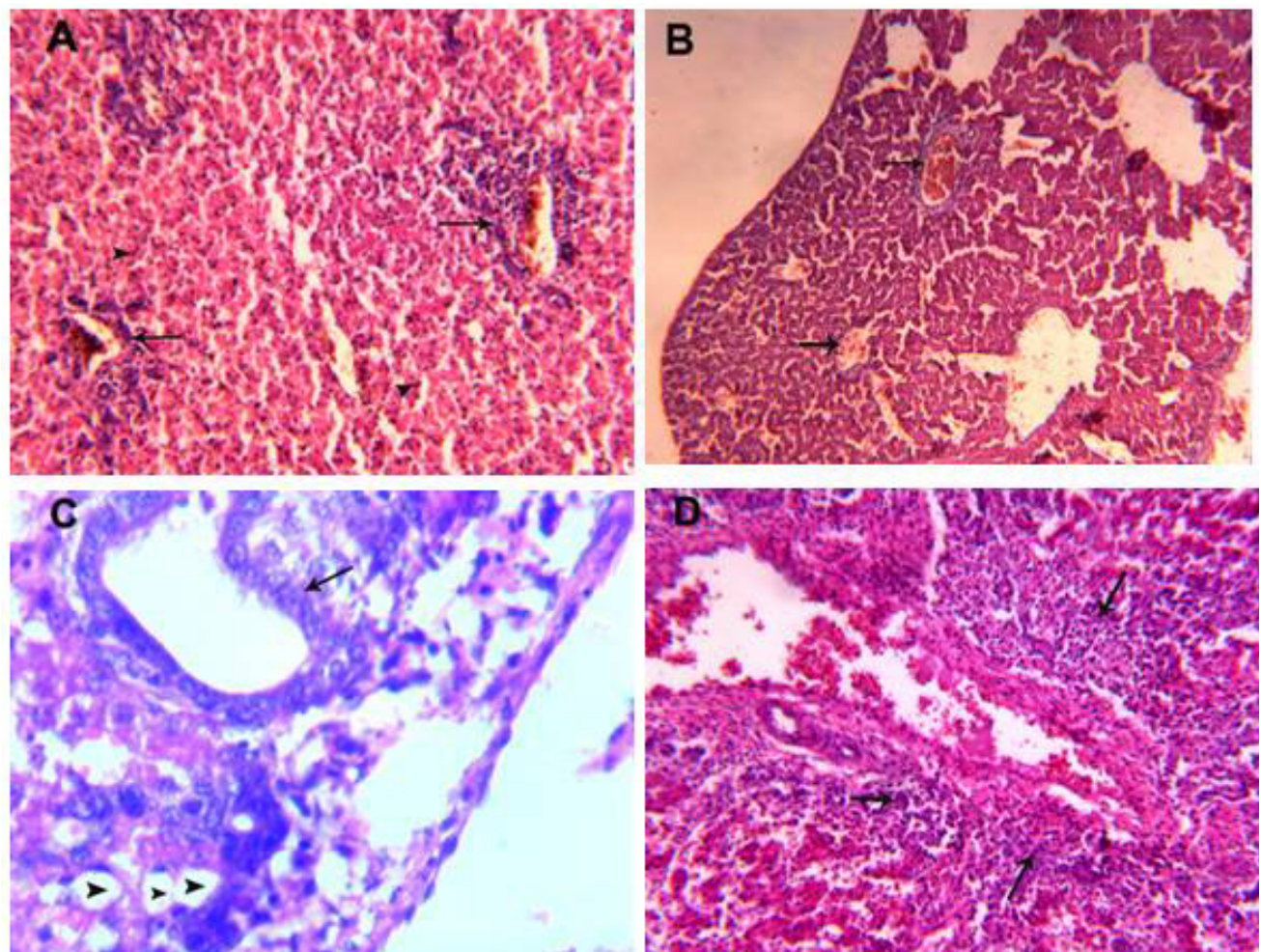

Figure 2: Liver of Mallard duckling, 8 days old showing marked inflammation in the portal tracts (arrows) H\&E x 200 (A). Liver of Mallard duckling, 8 days old showing dilated central veins engorged with blood (arrows) H\&E x 100 (B). Liver of Pekin duckling, 11 days old showing periportal vacculation of hepatocytes (arrow) H\&E x 300 (C). Liver of Pekin duckling, 6 days old showing portal area with congested hepatic artery and lymphatic infilteration (arrows) H\&E x 200 (D).

\section{RT-PCR analysis}

Using RT-PCR techniques with specific primers, The DHAV was detected in 22 out of 32 tissue samples with a percentage of $68.75 \%$. A DNA fragment of $467 \mathrm{bp}$ was amplified 3D gene for general detection of common DHAV (Figure 3).

\section{Discussion}

Sudden onset with rapid deaths among ducklings were recorded in different farms at Sharkia Governorate. In a trial to isolate and molecularly identify the causative agent, thirty two farms were subjected to the possibility of DHAV incrimination. The examined flocks revealed an acute lethal disease in ducklings
(2-11 days) of age. Our results are comparable with these of Woolcock [1] who observed similar disease among ducklings and explained that age resistance occurs at $\geq 7$ weeks of age. In the current investigation, the commonly recorded clinical signs among examined ducklings were lethargy, ataxia followed by opisthotonos then death. Rapid deaths frequently occurred within 1-2 hours after the onset of signs. Peaked mortalities in examined flocks occurred at $2^{\text {nd }}$ and $3^{\text {rd }}$ day after showing signs, and its course take 6-7 days as high as (up to 70\%). The obtained results were parallel to that previously recorded in DHV infection $[6,10]$. 


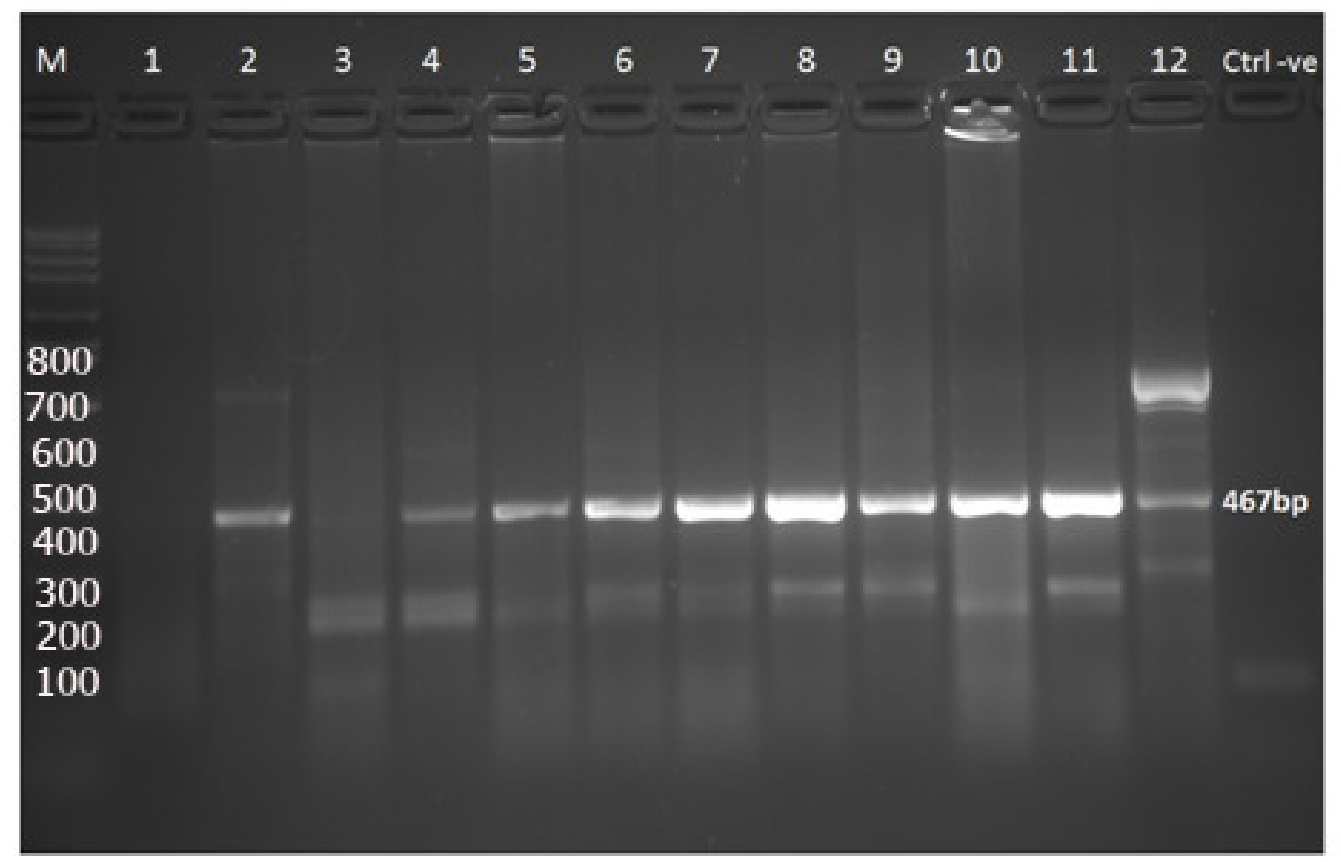

Figure 3: Molecular identification of DHAV using RT-PCR: Agarose gel electrophoresis of the RT-PCR products of DHAV. Lane M: DNA Ladder (marker) 100 bp. Lanes: 2, 4, 5, 6, 7, 8, 9, 10, 11 and 12 were positive at $467 \mathrm{bp}$. Lanes: 1,3 were negative. Lane ( $\mathrm{Ctrl}-\mathrm{ve})$ : negative control

Liver of examined ducklings were enlarged with distinct petechial and ecchymotic haemorrhages. Enlarged spleen was evidenced in 15 flocks. Ducklings also revealed enlargement of the kidneys with congestion of renal blood vessels in all flocks. Similarly, variable lesions were recorded among liver and kidneys [6, 30].

Histopathological examination of affected livers showed inflamed portal tract with marked dilatation and congestion of central veins and dilated sinusoids with hemolysed RBCs, massive hepatocyte necrosis, hydropic degeneration with variable fatty changes. These results were analogous to those reported by El-Samadony et al., who stated that hepatocellular necrosis in addition to vacuolar degeneration are present associated with dilated sinusoids with hemolysed RBCs in histopathological picture of affected livers [12].

Diagnosis of DHAV infection is based on virus isolation following the inoculation of tissue suspension from suspected ducklings into the allantoic cavity of 9-11 day-old ECE [31]. Our results included stunting and subcutaneous edema particularly of the head, abdominal and hind limbs with hemorrhages over the whole body. Enlarged embryonic liver with congestion necrotic patches were observed in inoculated ECE. The previously mentioned embryo lesions were reported as DHV pathological effect by many authors in previous studies [10] and [11].

Cheng et al [27] stated that reverse transcriptase polymerase chain reactions (RTPCR) have been developed for identifying DHAV infection. The partially magnified region of the 3D gene (467bp) of DHAV of our samples using RT-PCR was detected in 22 samples $(68.75 \%)$. Similarly, the presence of mentioned band indicates positive DHAV presence $[9,10,12]$. The RT-PCR confirmed the ECE inoculation results and consequently the RT-PCR could be a rapid and specific detection of the DHAV RNA as described by Liu et al [32] and Wei et al [33]. Although all investigated birds were aroused from vaccinated breeders against DHAV, the positive virus infection was watched in our study in $68.75 \%$ of examined progeny and in consequence tremendous economic losses up to $70 \%$ were recorded. The failure in 
protection by maternal derived immunity (MDI) may be attributed to low MDI or misapplication as well as the possibility of vaccination of challenge virus among vaccinal strains [10].

It could be concluded that RT-PCR could be carried out on hepatic tissues for rapid diagnosis of common DHAV. The subtyping of DHAV is useful for accurate diagnosis to avoid vaccine failure.

\section{References}

[1] Woolcock, P.R. (2003): Duck hepatitis. In: Saif, Y.M., Barnes, H.J., Glisson, J.R., Fadly, A.M., McDougald, L.R., Swayne, D.E. (Eds.), Diseases of Poultry., Eleventh ed. Iowa State University Press, Ames, IA, 343-354.

[2] Todd, D.; Smyth, V.J.; Ball, N.; Donnelly, B.M.; Wylie, M.; Knowles, N.J. and Adair, B. (2009): Identification of chicken enterovirus-like viruses, duck hepatitis virus type 2 and duck hepatitis virus type 3 as astroviruses. Avian Pathol, 38(1): 2129.

[3] Wang, L.; Pan, M.; Fu, Y. and Zhang. D. (2008): Classification of duck hepatitis virus into three genotypes based on molecular evolutionary analysis. Virus Genes, 37(1): 52-59.

[4] Kim, M.C.; Kwon, Y.K.; Joh, S.J.; Kwon, J.H.; Kim, J.H. and Kim, S.J. (2007): Development of one-step reverse transcriptase-polymerase chain reaction to detect duck hepatitis virus type 1. Avian Dis, 51(2): 540-545.

[5] Tseng, C.H. and Tsai, H.J. (2007): Molecular characterization of a new serotype of duck hepatitis virus. Virus Res, 126(1-2): 19-31.

[6] OIE, (2010): Duck Virus Hepatitis. OIE Terrestrial Manual 2010. (Chapter 2.3.8), available online at: http://www.oie.int/ fileadmin/Home/eng/Health_standards/tah m/2.03.08_DVH.pdf

[7] Levine, P.P. and Fabricant, J. (1950): A hitherto-undescribed virus disease of ducks in North America. Cornell Vet, 40:71-81.

[8] Refaie, E.R.M. (1969): studies on some diseases of ducklings with special reference to salmonellosis and duck viral hepatitis. Vet Med J, 16: 3-12.

[9] Sultan, H.A. and Talaat, S.M (2014): Isolation and Molecular Characterization of Duck Viral Hepatitis Disease Virus in Egypt. Submitted (24-NOV-2014) Birds and Rabbit Dis. Dept. Faculty of Veterinary Medicine, University Sadat City, Area No. 1 Sadat, Menoufiya 32511, Egypt).

[10] Erfan, A.M.; Selim, A.A.; Moursi, M.K.; Nasef, S.A. and Abdelwhab, E.M. (2015): Epidemiology and molecular characterisation of duck hepatitis A virus from different duck breeds in Egypt. J Vet Microbiol, 177(3-4): 347-352.

[11] Bayoumie, H.A.A. and Abd EL-Samie, L.K. (2015): Molecular characterization of a duck virus hepatitis isolate isolated from Sharkia governorate. Assiut Vet Med J, 61 (147): 56-65.

[12] EL-Samadony, H.A.; Tantawy, L.A. and Mekky H.M. (2016): Isolation and molecular detection of duck viral hepatitis. Global Veterinaria, 16(4): 314322.

[13] Tseng, C.H.; Knowles, N.J. and Tsai, H.J. (2007): Molecular analysis of duck hepatitis virus type 1 indicates that it should be assigned to a new genus. Virus Res, 123: 1902-1903.

[14] Priz, N.N. (1959): Comparative study of virus hepatitis in animals (dogs and ducks) using different routes of influence. Vopr Virusol., 696-700.

[15] Reuss, U. (1959): Virusbiologische Untersuchungen bei der Entenhepatitis. Transboundary and Emerging Diseases, 6(3):209-248.

[16] Asplin, F.D. (1965): Duck hepatitis. Vaccination against two serological types. Vet Rec, 77:1529-1530.

[17] Woolcock, P.R. (2008): Duck hepatitis. In: A Laboratory Manual for the Isolation, Identification and Characterization of Avian Pathogens, $5^{\text {th }}$ Edition, Dufour-Zavala L., Swayne D.E., Glisson J.R., Pearson J.E., Reed W.M., Jackwood M.W. and Woolcock P.R., 
eds. American Association of Avian Pathologists, Jacksonville, Florida, USA, 175-178.

[18] Guerin, J.L.; Albaric, O.; Noutary, V. and Boissieu. C. (2007): A duck hepatitis virus type $\mathrm{I}$ is agent of pancreatitis and encephalitis in Muscovy duckling. In: Proceedings of the $147^{\text {th }}$ American Veterinary Medicine Association $/ 50^{\text {th }}$ American Association of Avian Pathologists Conference, 14-18 July, Washington, DC, USA, Abs. 4585.

[19] Vertinski1̌, K.I.; Bessarabov, B.F.; Kurilenko, A.N.; Strel'nikov, A.P. and Makhno, P.M. (1968): The pathogenesis and diagnosis of viral hepatitis of ducklings. Veterinariia, 45: 27-30.

[20] Maiboroda, A.D. (1972): Formation of duck hepatitis virus in culture cells. Veterinariya, 8: 50-52.

[21] Hwang, J. (1969): Duck hepatitis virus-neutralization test in chicken embryos. Am J Vet Res, 30: 861-864

[22] Woolcock, P.R.; Chalmers W.S.K. and Davis, D. (1982): A plaque assay for duck hepatitis virus. Avian Path, 11(4): 607-610.

[23] Taylor, P.L. and Hanson, L.E. (1967): Indirect hemagglutination with duck hepatitis virus. Avian Dis, 11: 586-593.

[24] Gabridge, M.G. and Newman, J.P. (1971): Gel diffusion method for determining the titer of duck hepatititis virus. Appl Microbiol, 21: 147-148.

[25] Zhao, X.; Phillips, R.M. and Zhong, A. (1991): Studies on the detection of antibody to duck hepatitis virus by enzyme-linked immunosorbent assay. Avian Dis, 35(4):778-782.

[26] Ling, K.S.; Wechter, W.P. and Jordan, R. (2007): Development of a one-step immunocapture real-timeTaqMan RT-
PCR assay for the broad spectrum detection of Pepino mosaic virus. J Virol Methods, 144: 65-72.

[27] Cheng, A.; Wang, M.; Xin, H.; Zhu, D.; Li, X.; Chen, H.; Jia, R. and Yang, M. (2009): Development and application of a reverse transcriptase polymerase chain reaction to detect Chinese isolates of duck hepatitis virus type 1 . J Microbiol Methods, 77: 1-5.

[28] Jin, X.; Zhang, W.; Gu, C.; Cheng, G. and $\mathrm{Hu}, \mathrm{X}$. (2008): Identification and molecular analysis of the highly pathogenic duck hepatitis virus type 1 in Hubei province of China. Res Vet Sci, 85: 595-598.

[29] Suvarna, K.S.; Layton, C. and Bancroft, J.D., (2012): Bancroft's Theory and Practice of Histological Techniques EBook. Elsevier Health Sciences.

[30] Gough, R.E. and McNulty, M.S. (2008): Viral diseases In: Poult. Dis. PP. 350357. Edited by Pattison, McMulin, Broadbury and Alexander. Saunders El Sevier.

[31] Woolcock, P.R. (2010): DVH. In: Manual of Diagnostic Tests and Vaccines for Terrestrial Animals. Office International des Epizooties, Paris, France.

[32] Liu, G.; Wang, F.; Ni, Z.; Yun, T.; Yu, B.; Huang, J. and Chen, J. (2008): Genetic diversity of the VP1 gene of duck hepatitis virus type I (DHV-I) isolates from southeast China is related to isolate attenuation. Virus Res, 137: 137-141.

[33] Wei, C.Y.; Zhu, W.J.; Chen, J.D.; Zhao, F.R.; Wang, Y.J.; Xie, J.X.; Wang, H. and Zhang, G. (2012): Complete genome sequence of a novel DHAV discovered in southern China. J Virol, 86: 10247. 


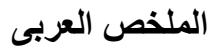

$$
\begin{aligned}
& \text { عزل والتعرف الجزيئى لقيروس التهاب الكبانى (A) بالبط فى محافظة الثرقية }
\end{aligned}
$$

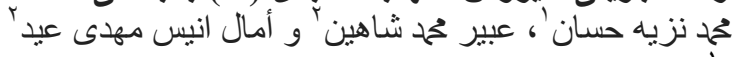

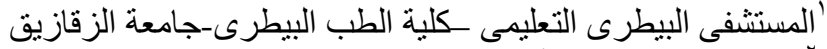

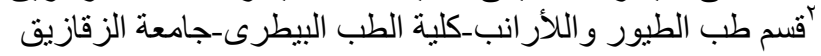

تم اختبار ثلاثين قطيع لاستبيان مسئولية فيروس الالتهاب الكبدى فى البط (DHAV) عن الأعراض العصبية والوفيات

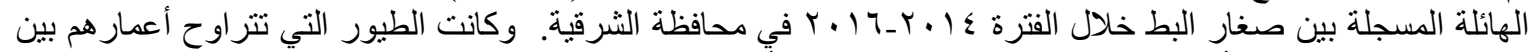

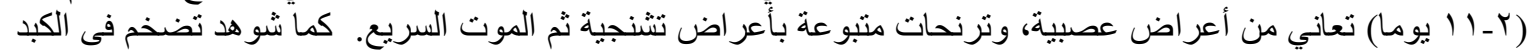

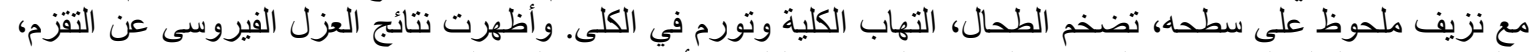

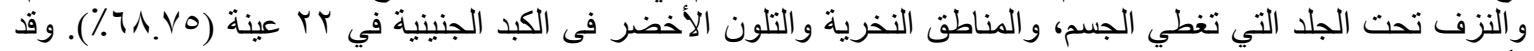

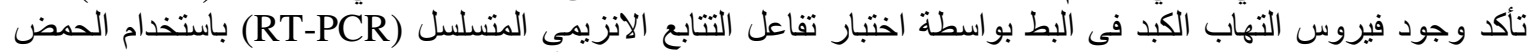

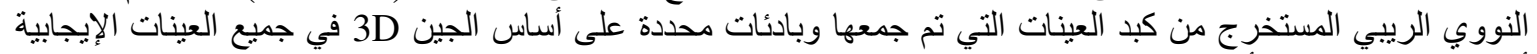

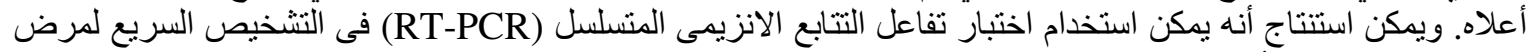
الالتهاب الكبدى من أنسجة الكبد فى الطيور المصابة ، واستخدام التصنيف الفرعى لفئل الفيروس الالتهاب الكبدى (DHAV) التشخيص دقيق لتجنب فنشل اللقاح. 